\title{
Governance and football: an examination of the relevance of corporate governance regulations for the sports sector
}

\author{
Stuart Farquhar*, Silke Machold and \\ Pervaiz K. Ahmed \\ University of Wolverhampton Business School \\ Telford Campus, Shifnal Road, Priorslee \\ Telford, TF2 9NT, UK \\ E-mail: S.S.Farquhar@wlv.ac.uk E-mail: s.machold@wlv.ac.uk \\ E-mail: pkahmed@wlv.ac.uk \\ *Corresponding author
}

\begin{abstract}
Concerns have been raised about the finance of football clubs in England and elsewhere. With the increasing realisation that football is a business, and therefore should be treated as one, the question of whether issues of corporate governance are applicable and relevant to the sports/football context needs closer scrutiny. This research firstly details current theories of corporate governance and proceeds with an examination of their limitations as approaches in the sports and specifically the football context. This paper delineates the characteristics and specific peculiarities of the sports sector, specifically football, and argues the challenges of corporate governance in sports are substantially different from conventional business as to require different approaches and mechanisms for corporate governance.
\end{abstract}

Keywords: corporate governance; sport/football economics; networks.

Reference to this paper should be made as follows: Farquhar, S., Machold, S. and Ahmed, P.K. (2005) 'Governance and football: an examination of the relevance of corporate governance regulations for the sports sector', Int. J. Business Governance and Ethics, Vol. 1, No. 4, pp.329-349.

Biographical notes: Stuart Farquhar is Senior Lecturer in the Department of Accounting and Finance at the University of Wolverhampton Business School. His research interests are in corporate governance, sports economics/finance and network theories.

Dr. Silke Machold is Principal Lecturer in International Business Strategy at the University of Wolverhampton Business School. Her research interests are transition economies and governance. Her more recent work has focused on normative dimensions of stakeholder theories, in particular feminist ethics and governance.

Professor Pervaiz K. Ahmed is Director, Japanese Management Research Unit, and Head of the Centre for Enterprise Excellence. He is full Professor at the University of Wolverhampton, UK where he holds the Chair in Management. $\mathrm{He}$ has published numerous papers in international journals and acted as keynote speaker at international platforms. He currently serves on the editorial board of a number of international journals. 


\section{Introduction}

Interest in corporate governance has heightened in recent years due to an increase in financial scandals in major organisations such as Enron and WorldCom. Simultaneously, concerns have been raised about the financial plight of a number of football clubs. This has led to an increased interest in the corporate governance within football clubs. The extent of this interest can be demonstrated by the setting up of a special research centre in Football Governance at Birkbeck College, University of London.

Traditional approaches to corporate governance and regulations pertaining to corporate governance in the UK (e.g., Cadbury Report, etc.) and elsewhere have primarily focused on public limited companies where the separation of ownership and control (Berle and Means, 1932) has led to concern over whose interests are being looked after by the managers of such corporations. The recent financial difficulties in the football industry have led to increased interest in the governance of this particular sport. This paper suggests that a different approach to the corporate governance of football is necessary from approaches prevalent in other industries. The paper is organised as follows. The first section examines theoretical frameworks in corporate governance. The second section highlights the differences between the professional sports industry, and specifically team sports, from conventional industry. The third section looks at the specific governance issues in football and some of the problems in conceptualising governance in football through traditional theoretical lenses. The paper concludes with an identification of further avenues of research in the field.

\section{Corporate governance}

Shleifer and Vishny (1997) describe corporate governance as the ways in which suppliers of finance to corporations assure themselves of getting a return on their investment. Aoki (2000) suggests that corporate governance is concerned with "the structure of rights and responsibilities among the parties with a stake in the firm". Daily et al. (2003) define governance as the determination of the broad uses to which organisational resources will be deployed and the resolution of conflicts among the myriad participants in organisations. Alternatively, Denis and McConnell (2003) define corporate governance as the set of mechanisms both institutional and market-based that induce the self-interested controllers of a company (those that make decisions regarding how the company will be operated) to make decisions that maximise the value of the company to its owners (the suppliers of capital). Thus researchers have not accepted one unique definition of corporate governance. Aguilera and Jackson (2003) suggest this lack of common definition is not that surprising given the diversity of practices across the world. This lack of common definition also is indicative of the considerable number of different approaches that have been taken in corporate governance research. A variety of theories have been advanced in corporate governance from the disciplines of economics, finance, law, organisational theory, sociology and strategic management. This section will examine the three principal theories of corporate governance: agency theory, stewardship theory and stakeholder theory. 


\subsection{Agency theory}

The dominant theoretical perspective applied in corporate governance research is agency theory. Agency theory derives from economics and finance predominately as an attempt to explain the success of modern corporations despite the separation of ownership and control, first given prominence by Berle and Means (1932). Jensen and Meckling (1976) proposed agency theory as an explanation of how the public corporation would exist, given the assumption that managers are self-interested, and a context in which those managers do not bear the full wealth effects of their decisions. Since Berle and Means (1932) first gave prominence to the 'Separation of Ownership and Control' thesis within modern corporations, there had been little theoretical literature in economics that could satisfactorily explain the success of organisations where ownership and control were in the hands of different people. Agency theory is based on the premise that the modern corporation is run by managers (agents) on behalf of owners (principals) and that managers attempt to maximise their own utility rather than the utility of the owners. Agency theory had the key advantage of explaining the way modern firms could survive and prosper despite the difficulties that arise when self-interested managers have control in the organisation owned by its shareholders.

Agency theory lends itself to a number of predictions that have led to a considerable body of research. Dalton et al. (2003) divide this research into two broad themes. The first they refer to as 'alignment' and the second is what they term 'control'.

The alignment view is broadly concerned with the achievement of congruence in the interests of owners and managers (Fama and Jensen, 1983; Fama, 1980; Jensen and Meckling, 1976), based on the premise that there is an inherent conflict between the interest of a firm's owners and management (Fama and Jensen, 1983). The solution to the problem of managerial self-interest is to align the interests of owners and management through compensation packages, which are based on the performance of the company, and include providing managers with equity stakes in the firm. This solution would help ensure managers' and owners' interests were more closely aligned and that by achieving this it is presumed firm performance will be improved (Jensen and Murphy, 1990). In this case, the executives' wealth should be closely and directly correlated with company performance. Without an equity investment in a firm, executives are more likely to behave opportunistically by supporting investments that further their own interests; at shareholders' expense, and to behave in a manner that further enhances their job security (Himmelberg et al., 1999). This self-interested behaviour was identified by Eisenhardt (1989) as a fundamental element of agency theory. Thus, agency theory suggests inside directors should own significant levels of company stock.

The control approach concerns the monitoring of firms' management and suggests concentrated shareholdings may facilitate the monitoring of managers' performance and lead to improved firm performance. According to Demsetz and Lehn (1985) the ownership shares of two types of outside owners, institutions and 'blockholders', are typically sufficiently large that these equity owners are in a position to see to it that management serves their interests and this monitoring should lead to higher profit rates.

Thus, the clear implication for corporate governance from an agency perspective is that adequate monitoring or control mechanisms need to be established to protect shareholders from management's pursuit of self-interest. This is required as a 
consequence of the so-called agency costs of modern capitalism (Fama and Jensen, 1983). Consequently, various studies have examined the recommendations that arise from agency theory in terms of corporate governance controls, which are necessary in order to ensure that managers act in the best interest of shareholder. These specifically relate to a number of key matters, including the relationship between board size and organisational size, size of board and firm performance, proportion of outside directors and firm performance, CEO duality and firm performance.

According to agency theory, large companies require a greater number of directors to monitor and control a firm's activities. A larger board is likely to be better able to monitor agency problems because a greater number of people will be reviewing management's actions. However, agency theorists recognise that there is an upper limit to boards. Jensen (1993) suggests this limit is about eight directors, as any greater number will interfere with group dynamics and inhibit board performance.

An alternative perspective is that it is not the size of the board that matters, per se, but rather the number of outside directors on the board. With respect to board composition, agency theory suggests a greater proportion of outside directors will be able to monitor the actions of self-interested managers (Fama and Jensen, 1983; Fama, 1980). Thus, firms with higher proportions of outside directors on their board should show superior levels of performance compared with firms dominated by inside directors. Agency theorists argue that the same person should not hold the Chief Executive Officer (CEO) role and chairman role simultaneously, as this will reduce the effectiveness of board monitoring.

Additional to the predictions and studies of internal governance monitoring and controls is the prediction from agency theory that an alternative governance device can be found in a well-developed external market for corporate control. In this respect takeovers replace the failings of internal control mechanisms as a governance device (Walsh and Seward, 1990). Because of the expense of the external mechanisms to the principal's utility, internal mechanisms are generally preferred (Walsh and Seward, 1990). External controls such as the market for corporate control are important as they can help reduce the costs to shareholders of the failings of internal mechanisms.

A recent meta-analysis study by Dalton et al. (2003) find no support for agency theory's proposed relationship between ownership and firm performance. In addition their study finds relatively low relationships between categories of equity and multiple indicators of financial performance.

Whilst agency theory has been the dominant approach in corporate governance research there has been an increased interest in other theories of governance.

\subsection{Stewardship theory}

Stewardship theory takes a somewhat contrasting view to agency theory in its approach to corporate governance. Whereas agency theory has its roots in economics and finance, stewardship theory has its roots in psychology and sociology. Here, managers are regarded as essentially trustworthy individuals who will look after the interests of the owners of the corporation (Donaldson and Davis, 1991a; Davis et al., 1997). Stewardship theory derives from a view of the model of man whose behaviour is ordered somewhat differently than that which is viewed in agency theory. In stewardship theory, the model of man is based on a view that man is predominately pro-organisational and collective in 
his outlook whereas agency theory derives from 200 years of research in economics where man is portrayed as individualistic and self-serving.

Proponents of stewardship theory contend that superior corporate performance will be linked to a majority of inside directors as they work to maximise profit for shareholders. This is based on a view that because inside directors understand the business they can govern better than outside directors and so can make superior decisions (Davis et al., 1997; Donaldson and Davis, 1991b; Donaldson, 1990). The principal rationale underlying this assertion is that since managers are naturally trustworthy there will be no major agency costs (Donaldson and Preston, 1995). Therefore, stewardship theorists contend that the board of directors should have a significant proportion of inside directors to ensure more effective and efficient decision-making. This prediction is exactly the opposite of agency theory.

Stewardship theorists, furthermore, argue that senior executives will not disadvantage shareholders for fear of jeopardising their reputation (Donaldson and Davis, 1994). The reputation of senior executives is key here as their own utility is lowered if they are seen as not acting in the interests of the organisation. To that extent, CEO chairman duality is seen as a positive force, because there is clear leadership for the company.

Similar to agency theory the empirical evidence in support of the predictions of stewardship theory is mixed. Indeed Davis et al. (1997) in their development of stewardship theory of management suggest their model requires managers to choose to behave as stewards or agents and that their choice is dependent on their psychological motivations and perceptions of the situation.

\subsection{Stakeholder theory}

Despite the differences in the 'model of man' proposed by agency theory and stewardship theory, they share common ground as far as they accept the primacy of shareholders. Stakeholder theory, however, does not accept the primacy of shareholders and has developed a high degree of recent prominence.

Stakeholder theory addresses the issue of corporate governance in a different way. Whereas agency theory and stewardship theory are primarily based on the objective of the firm being to maximise shareholder value, the stakeholder theory of the firm suggests that the corporation's objective should be to maximise the interests of the stakeholders of the organisation. Stakeholder theory initially developed by Freeman (1984) suggests that managers should balance the shareholders' financial interests against the interests of others stakeholders such as employees, customers and the local community even if it reduces shareholder returns.

A useful framework for looking at the burgeoning literature in stakeholder theory is given by Donaldson and Preston (1995). They propose three stakeholder theory types: normative, instrumental and descriptive. Jones and Wicks (1999) explain the three-part typology of Donaldson and Preston simply. Firms/managers should behave in certain ways (normative); certain outcomes are more likely if firms/managers behave in certain ways (instrumental) and firms/managers actually behave in certain ways (descriptive). Developing this typology in more detail, the normative form of stakeholder theory primarily focuses on how organisations should manage corporate stakeholders. Phillips et al. (2003) suggest stakeholder theory is a theory of organisational management and ethics, and therefore seeks to connect the economic and moral. Jawahar and McLaughlin 
(2001) suggest that the normative perspective literature prescribes how all stakeholders should be treated on the basis of some underlying moral or philosophical principles. The foundation of normative stakeholder theory is usually given moral justification and drives the view that firms should pay attention to all their stakeholders and not just their shareholders.

Instrumental stakeholder theory addresses the issue between the practice of stakeholder management and the achievement of various corporate performance goals. Here the suggestion is that those corporations that effectively manage stakeholders will achieve superior levels of corporate performance. Jones (1995) through a synthesis of ethics and economics proposes that if firms contract with their stakeholders primarily through their managers on the basis of mutual trust and cooperation, they will have a competitive advantage over firms that do not. The implicit inference deriving from instrumental theory is that firms that take a stakeholder approach will outperform those that take a shareholder approach.

The third perspective deals with descriptive theory of stakeholders. Here the focus is on describing what the corporation is. Donaldson and Preston (1995) explains this concept very well, "It describes the corporation as a constellation of cooperative and competitive interests possessing intrinsic value" (p.66). Stakeholder theory could be seen as a development of behavioural theories of the firm (Simon, 1959; Cyert and March, 1963) where there was explicit recognition of the different parties who could be viewed as having a stake in the organisation. Behavioural theorists contended their model of the firm was closer to descriptive reality than the neoclassical profit-maximising model and thus could be described as a precursor to stakeholder theory.

The use of stakeholder theory as a model in which to examine corporate governance was first suggested by Freeman and Evan (1990). Utilising Williamson's transaction cost framework for analysing firms, Freeman and Evan proposed incorporating contractual theory as an analytical framework in which to examine the multiplicity of stakeholders within an organisation. According to Freeman and Evan (1990), Williamson (1984) places corporate governance centrally within the modern theory of the firm. Williamson suggested that the accordance of voting rights in a firm should be limited to those who share the residual risk of the firm and that this group consists of owners (shareholders), and only under special circumstances, managers, and suppliers. This conclusion derives from his view that the firm is seen as a governance mechanism for a set of contracts between interested parties who make economic gains through their participation in these contractual relationships. According to Williamson, there are a variety of governance mechanisms to those parties who have a stake in the firm. The stakeholders identified by Williamson are customers, suppliers, owners, managers, employees and communities. Like stakeholder theory, Williamson's view implicitly draws upon some of the ideas in the behavioural theories of the firm of Simon (1959) and Cyert and March (1963).

Freeman and Evan (1990) suggest the logical outcome from the Williamson approach is that stakeholders are accorded voting rights with respect to deciding how the corporation was managed. This interpretation derives from a view that the central feature of the contracts framework is the emphasis on the priority of bargaining by parties to the contract. "Once this priority of bargaining is recognised, it becomes desirable to consider a framework for the firm as a series of multilateral contracts among stakeholders" (Freeman and Evan, 1990,p.354).

Stakeholder theory adds some interesting dimensions to the corporate governance debate. Shareholder-based theory approaches dominated by agency theory clearly 
identify that we should judge a firm by its success in enhancing shareholder value. Stakeholder theory advocates a different measure of success: maximising the balanced interests of the stakeholder groups of which shareholders are just one. Those that oppose stakeholder approaches contend such an approach lacks one clearly defined objective function on the basis of which the success of the firm can be measured (Jensen, 2002). The use of Corporate Social Performance (CSP) measures may be a potentially useful measure to overcome this problem (Clarkson, 1995). However, as yet there appears little usage of such measures and consequently little empirical support. Instrumental stakeholder researchers have suggested those companies that successfully manage the company in interests of the stakeholders also achieve higher levels of financial success. The suggestion is that corporations benefit financially through taking a stakeholder perspective (Jones, 1995). However, the measures used are economic. Whilst critics of stakeholder theory would concur with the sentiments that value maximisation can only be achieved by an organisation recognising the stakeholders, they suggest the lack of one determinate objective function renders stakeholder theory incompatible with value maximisation (Jensen, 2002). In a recent response to some of the criticisms of stakeholder theory, Phillips et al. (2003) contend that stakeholder theory is compatible with value maximisation. They suggest it is not value maximisation that is the issue, but to whom the rewards of the organisation's profits are distributed.

This leads into further contention arising from stakeholder theory. A number of theorists have argued that measures of CSP and other similar concepts are dependent on a power game in terms of determining which stakeholders matter and who counts most (Trevino and Weaver, 1999). Indeed, a number of researchers have attempted to develop stakeholder theory through an identification of who the stakeholders are and who or what really counts (Mitchell et al., 1997; Rowley, 1997; Agle et al., 1999; Jawahar and McLaughlin, 2001). Using the Donaldson and Preston terminology the first question addresses the normative theory, to explain why managers should consider certain groups as stakeholders. The second question requires a descriptive theory, to explain the conditions under which managers do consider certain groups as stakeholders.

Whilst there is a considerable body of literature on stakeholder theory there is little specifically applying the theory to governance research. In an attempt to place stakeholder theory in a corporate governance context Hendry (2001) has criticised the normative stakeholder theory on grounds that where stakeholder theory is purported to be a theory of organisational management and ethics (Phillips et al., 2003) it bases the normative theories on an economic model of the firm. He bases his contention on the grounds that in order to be viewed as a theory of ethics, stakeholder theory requires a social model of the firm in which to analyse the stakeholder relationships. Hendry's (2001) critique of stakeholder theorists using an economic model is analogous to a comparison between apples and pears. When you attempt to provide a theory that is moral you cannot use economic approaches to determining value. You are not comparing like with like. That stakeholder theory attempts to determine the rights of stakeholders based on a contractual aspect of economic relations is to Hendry no more than reducing stakeholders to merely economic entities. For Hendry, the consequences are such that:

\footnotetext{
"The stakeholder problem then reduces to one of the division of the economic spoils of the business, and the claim that businesses should be managed for the benefit of all and their stakeholders gives rise to the obvious and apparently devastating riposte: how, then is the economic value to be divided between stakeholders?" (Hendry, 2001,p.225)
} 
The problem here is that stakeholder theory cannot easily provide an answer to such a question. Shareholder theory addresses the answer; simply allocate the residual profits to the owners (shareholders). Stakeholder theory requires either a workable structure of negotiation or an introduction of non-market criteria for stakeholder responsibility. Hendry claims the former compromises the more demanding versions of stakeholder theory, whilst the latter is ruled out by the adoption of the economic model of the firm. This critique about the outcome measure of stakeholder theory is one supported by agency theorists such as Jensen, and would suggest that stakeholder theory is under attack from many directions. If Phillips et al. (2003) contend that stakeholder theory is about the distribution of profits the lack of a measuring device to determine the apportionment of such rewards leaves questions over the validity of the stakeholder approach as a theory in the truest sense of the word.

In developing a social model of the firm, Hendry (2001) justifies the need for a different approach to an ethic of business and corporate governance on the grounds that whereas businesses are social, economic and legal constructions ethics is not primarily about economics and law, but about social relationships between moral actors. Hendry bases his model on the basis of a system of social relationships. He defines the social model as particular combination of relationships. For example, Hendry proposes that there are relationships within the board of directors, in which the CEO occupies a dual role as director and employee. He suggests that economic perspectives treat the board as shareholder-monitoring device, a view that conforms to the shareholder theory. He also adds that directors are not just monitors, but are central to the company and legally responsible for its conduct. This latter view is similar to stewardship theorists such as Donaldson and Davis. Indeed one could view Hendry's model of the firm as bringing together agency and stewardship perspectives on corporate governance and that it is primarily due to the assumptions Hendry makes in developing his model. The importance of the assumptions, not least the separation of legal, economic and social relations Hendry makes in developing his model is an area that requires further research.

Aside from the issue of whether stakeholder theory is a theory or not, there has been little empirical research testing the contention that a balanced stakeholder approach enhances financial performance. One study that examined whether a stakeholder approach did enhance financial performance was undertaken by Berman et al. (1999). Based on a stakeholder model including employees, the natural environment, diversity of workforce, customers/product safety and community they undertook two broad tests. The first related to strategic stakeholder management model and the second on intrinsic stakeholder commitment model. The former is based on the hypothesis that managers will attend to stakeholders' interests to the extent that these stakeholders are important. The latter is based on the view that the interests of stakeholders have intrinsic value and that managerial commitment to stakeholder interests will drive strategic decision-making, which in turn will affect firm performance. Their results provide some support for the strategic stakeholder model, though not for all the stakeholders identified, but no support for the intrinsic stakeholder commitment model. This result lends credence to the arguments espoused by Jensen (2002) that stakeholder theory is consistent with value maximisation, which implies that managers must pay attention to all stakeholders that can affect the firm, as long as the measure of performance is based on a shareholder approach. 


\title{
3 The sports industry
}

These theories of corporate governance have all concentrated on issues of governance at the level of the firm. The professional sports industry, however, has a number of important differences from conventional industries that suggests professional team sports require a different approach to corporate governance than conventional industries. In this section these differences will be highlighted.

As a product, professional sport requires coordination among contesting participants because the main product, a game, involves at least two distinct entities. Team sport requires that teams must agree on a number of matters before the game or competition takes place. This coordination is essential if there is to be any competition in professional team sports. It is predominately for this reason that sporting leagues have been established as the organisational focus for professional team sports. This organisational dimension will be returned to later. In other industries such coordination is generally seen as anathema as it would be viewed as anti-competitive. Without coordination, professional sport competition would not occur. It is also clear that one team cannot obtain revenue without another team to play with. The financial viability of a sports team is thus dependent on the success of other sports teams. This unique characteristic was highlighted by Rottenberg (1956) in his seminal paper on professional sport:

\begin{abstract}
"Professional team competitions are different from other kinds of business ventures. If a seller of shoes is able to capture the market and cause other sellers of shoes to suffer losses and withdraw, the surviving competitor is a clear gainer. But in baseball no team can be successful unless its competitors also survive and prosper sufficiently so that the differences in the quality of play among teams are not too great." (Rottenberg, 1956,p.244)
\end{abstract}

This quote suggests another important 'unique' characteristic of professional team sports: the importance of balanced competition or 'uncertainty of outcome' to the financial success of professional sports teams.

The theoretical literature argues competitive imbalance, or on-field domination of one or a small number of teams (organisations) reduces the level of uncertainty of outcome and consequently reduces the level of consumer demand and thereby the revenue gained by sports individuals or teams (Rottenberg, 1956; Neale, 1964; El-Hodiri and Quirk, 1971; Fort and Quirk, 1992; 1995; Vrooman, 1995; Kesenne, 2000a; 2000b).

This uncertainty of outcome hypothesis has been the subject of a body of empirical literature and the results have been mixed in terms of their support. A number of studies have shown support for the uncertainty of outcome hypothesis (Jennett, 1984; Cairns, 1987; Peel and Thomas, 1997; Szymanski, 2001; Schmidt and Berri, 2001) whilst other studies have shown weak or no support (Whitney, 1988; Peel and Thomas, 1988; 1992; Baimbridge et al., 1996). These mixed results led both Downward and Dawson (2000) and Szymanski (2003) to reach similar conclusions that the uncertainty of outcome hypothesis has been over-emphasised in importance in sporting leagues. However, Downward and Dawson (2000, 2003a; 2003b) suggest the ambiguous results might partly be due to problems with the measures of competitive balance employed in the empirical work. Regardless of the empirical findings on whether 'uncertainty of outcome' is an important determinant of demand it is true to state that competition is essential to revenue and profit generation. 
The above reemphasises the previous discussion on the market structure of sport compared to other industries. Whereas firms can continue to exist with no rivals in other industries this is clearly impossible in sport. However, monopoly can and does exist in sport but at the level of the league and not the team. Team sports are almost always organised into leagues. This league structure is unique to sport, other industries have no structures that bring firms together to organise the competition between them, other than in the very few industries with legal cartels. This organisational structure has significant dimensions when considering a model of corporate governance in professional team sports. Noll (2003), taking an approach similar to Flynn and Gilbert (2001), suggests teams in sport must make at least five types of decisions about league structure. These include the method of scheduling matches to determine the champion; the relationships between leagues of lesser and greater quality; the number of leagues at the same level of the hierarchy; the conditions under which a team enters and exits a league; and the methods for deciding and enforcing league rules and policies. This last issue relates to the governance of the league and demonstrates how issues of governance in team sport have a league dimension as well as a firm-level one. Existing models of corporate governance are based at the level of the firm and thus the sports industry poses some interesting additional questions when considering a model of governance.

The literature on sports leagues provides three approaches when analysing sports leagues. A brief examination of each should further illustrate the different context of sport. Neale (1964) suggested that a sporting league was a natural monopoly. A league requires one champion and where more than one league exists without a form of play-off, the true champion would be unknown. In addition a single organised structure would be able to provide the product at cheaper cost and therefore a monopoly supplier would be the most efficient. Neale (1964) suggested the league was a monopoly firm and the member teams were simply multi-plant divisions of the monopoly firm.

Sloane (1971), in the first paper applying economic analysis to the British football industry, provided a critique of Neale's view that a sporting team was not in itself a firm. Sloane suggested that professional sports leagues could be more usefully viewed as a cartel where the league is the central organising body of the cartel with the clubs being member firms of the cartel. Sporting leagues display various features typical of cartels. These include some or all of the following: determination of the size of the league (i.e., the number of producers), the location of clubs/franchises (points of production), the allocation of playing talent (resources), pricing policies, marketing and merchandising sales, arrangements for sharing revenues and fees paid by TV companies and sponsors. Sporting leagues also tend to have consecutive rule-structures, because change must be acceptable to a majority of members, resulting in internal tensions between the interests of individual clubs and the league as a whole. Whilst cartel arrangements are generally seen as being unlawful in most industries in sports they are often viewed as a necessary feature. This is another reason to suggest that professional sport is different.

The third way of looking at professional sports leagues was first advocated by Flynn and Gilbert (2001) who argue that sports leagues are akin to joint ventures. Noll (2003) also viewed professional leagues as joint ventures. Most professional sports leagues are organised in similar ways. Member teams are independently owned and managed and collectively create the league as a joint venture for coordinating the league activities. There is a chief executive of the league and the team owners constitute the board of directors. The chief executive may have considerable authority in the league's rules and policies, but true power lies in the hands of team owners. Flynn and Gilbert (2001) 
contend that to efficiently produce a commercially attractive product, professional sports leagues have established a structure of rules and decision-making procedures.

Flynn and Gilbert (2001) also suggest that members of a professional sports league do not compete with each other or with the league in the ex ante sense of providing competition in the market for professional sports, because the organisation provided by the league is crucial to the product. It is unlikely football fans would see friendly fixtures as close substitutes for league-organised games leading to a league championship title. In addition to this lack of ex ante competition, Flynn and Gilbert (2001) suggest the individual members of a sports league are not competitors in the ex post sense for many purposes. Here, Flynn and Gilbert (2001) contend that teams may be competitors on the field, but they do not compete in the economic sense. This is a somewhat contentious argument given that in European sports teams compete in many revenue-generating activities, including merchandising, broadcasting sales and others, with other teams as well as other leisure industries. It might have more applicability in a number of US sports where a number of these activities are done at the level of the league. Whether this lack of economic competition is evident in sport the contention of Flynn and Gilbert (2001) is useful in that it further illustrates the importance to sports teams of having good, close on-field competition for them to survive economically.

A further organisational issue that emerges from using a cartel approach or a joint venture approach to analysing sports leagues is that of league and firm objectives. Agency and stewardship theories of corporate governance both take the view the firm is aiming to maximise shareholder value, whilst stakeholder theory contends the firm should maximise the balanced interests of the various stakeholders. The literature in sport identifies three different objectives for firms. The majority of research into US sports (Rottenberg, 1956; Neale, 1964; El-Hodiri and Quirk, 1971; Fort and Quirk, 1995; Vrooman, 2000; 1997; 1995; Fort, 2000) takes the assumption that teams attempt to maximise profits for the owners and the league attempts to maximise the joint profit for the member teams. UK and European based research traditionally take a different approach. Sloane (1971) suggested utility maximisation was a more relevant objective applied to British football. A more recent approach has been to suggest owners aim to maximise win percentage (Szymanski and Smith, 1997; Kesenne, 1996; 2000a; 2000b).

To sum up, sporting leagues are unusual markets because clubs must actively cooperate to produce their (joint) product. The likelihood that evenly matched contests will attract more customers suggests that leagues should be of near-equal ability, as dominance by a small number of clubs reduces both the interest of the viewing public and the overall amount of attendance revenue the league should receive. In addition, sporting leagues have a number of organisational issues that are not applicable to other industries including decisions on format, hierarchy, multiplicity, membership and governance. This suggests professional team sports have an added complexity in terms of corporate governance and that is governance at the level of the league as well as the firm. Important questions develop from this particular issue. To what extent is the governance of the league a function of the teams or firms and to what extent is the governance of team/firm a function of the league? Traditional approaches to governance are readily applicable to situations where the boundaries of the firm are clear, however they are not so easily applied in cases where the boundaries are more open. Given this argument that professional sport is different, the next section will examine the specific issues relating to corporate governance in English football. 


\section{Governance in football}

Governance in football is a somewhat complex subject matter. Football in England is organised through the Football Association (FA). The FA is a member of the world governing body in football, The International Federation of Football Associations (FIFA) and also belongs to the Union of European Football Associations (UEFA), a subordinate of FIFA. FIFA is responsible for world-level competitions such as the World Cup and UEFA is responsible for European competitions such as the European Championship for national associations, and the European Champions League a European-level competition for clubs who qualify through success in their domestic leagues and cup competitions. The FA has responsibility for all levels of football throughout England. This includes the amateur and professional game at senior and junior level. All teams in the English league structure are members of the FA, although the FA does not organise all the leagues. Thus, the system of governance in football could be viewed as a network arrangement and requires a model of network governance in which to analyse it.

The league structure is based on a hierarchy of leagues. The hierarchy is extremely deep, with ten levels of the FA (including the upper and lower divisions of some lower minor leagues. The Premiership is the top league of the hierarchy and currently consists of 20 teams and is organised by the FA. The next three divisions in the ladder are organised by the football league and each of these consists of 24 teams. Before the breakaway of the top division teams with the setting up of the FA Premier League in 1992, the top four divisions were all under the auspices of the football league. Even though the Premiership is run by the teams in the league under the auspices of the FA separately from the football league divisions, there is promotion and relegation throughout the hierarchy. Firms are freely able to enter the hierarchy at the bottom rung of the ladder, but are not able to enter straight into the upper echelons of the hierarchy. The league system is an open one with promotion and relegation enabling teams to move up and down the hierarchy. The issue of promotion and relegation and its effect in terms of governance will be returned to later.

The vast majority of football clubs in the Premiership or football leagues are incorporated as public or private companies and their objectives (as stated in their Memorandum and Articles of Association) include both promoting football as a sporting activity and as a business. The relationship between these objectives is somewhat complex and has implications for the corporate governance and financial performance of football clubs. Hall et al. (2002), using a Granger causality test, show that a causality of higher payrolls to better performance in English football cannot be rejected. This suggests clubs that spend more on players are more likely to win, and if better on-field performance improves revenue generation then clubs have a strong incentive to invest in better quality players. Furthermore, if the revenue streams attached to winning increase relative to not winning, there might be considerable encouragement to clubs to gamble on success, even when this risks sound business practice. In this respect the governance of clubs (firms) in football is a very important aspect.

\section{Proposition 1: Higher revenues gained from greater on-field success increases the incentives for football clubs to take financial risks.}

A second issue emerges from the relationship between football as a sporting activity and football as a business and that is a question of what the principal objective is. While firms 
in other industries might have multiple objectives the overriding one for public companies is to maximise the value of the business for the owners (shareholders). As previously discussed most US-based research takes the view that teams (firms) aim to maximise profits. Literature on European sports tends to take alternative perspectives on the objectives of sports teams. Sloane (1971) suggests football clubs are less profit-oriented than other commercial organisations. He argues that clubs are firms endeavouring to maximise utility and not the traditional business objective of maximising profit. Both agency theory and stewardship theories, as applied to corporate governance, both take the view that firms aim to maximise profit these seem to have limited application in football. Additionally, many football clubs are single proprietorships and therefore the typical agency issues arising from a separation of ownership and control do not apply. These agency issues may, however, apply to football clubs that are public limited companies. Indeed, the often-voiced concerns from supporters have been directed at football clubs who have become public limited companies and are listed on the London Stock Exchange. These are predominately based on the view that economic or business matters will dominate at the expense of football matters. Alternatively, there are those who contend football clubs should be run as businesses. Some authors (e.g., McMaster, 1997) have suggested that extension of share ownership through private clubs going public would enhance the financial performance of football clubs. However, analysis by Szymanski and Hall (2003) (in Zimbalist, 2003) on 16 FA clubs that went public since 1995 suggests that there was no significant difference in the financial performance of these clubs. The results obtained by Szymanski and Hall (2003) to some extent undermine the view that going public will change the objectives of football clubs. These results do not, however, shed light on the actual objectives. This finding is consistent either with the argument that football clubs are still utility maximisers after going public or the argument that clubs have always been profit maximisers.

According to standard agency theory, problems arise because of the separation of ownership and control. This suggests agency problems would be more likely to occur in public limited companies with widely dispersed share ownership. In football, the evidence of Szymanski and Hall (2003) previously presented suggests financial performance is not significantly affected by changes in ownership structure. Given that many football clubs remain privately controlled, where the normal problem of agency, the division of ownership and control, does not apply, agency theory explanations of poor financial performance of football clubs do not appear very convincing. According to Fama and Jensen (1983), firms' underlying agency problems are resolved by the interaction of various markets. The efficient functioning of those markets allows principals effectively to monitor agents' conduct and performance, and moreover, provides agents with the incentives to monitor their peers. Specifically, Fama and Jensen (1983) judge that a market for corporate control, an internal labour market and a market for directors, if they operate efficiently will bond agents' interests to their principals. A market for corporate control is deemed to be of particular importance in ensuring the convergence of objectives. If the incumbent board of directors is perceived not to have performed in the best interests of principals then these principals may ultimately sell their ownership rights. If sufficient numbers undertake this exercise the value of the corporation's stock will decline, making it a target for takeover: the implication being that incumbents' positions will be threatened. The threat of a takeover and of exit through business failure (liquidation) provide necessary controls on the actions of agents to act in 
the interest of principals. However, prima facie evidence suggests these rarely occur in football. It thus appears that there is a lack of a market for corporate control in football.

This lack of a market for corporate control in football led McMaster (1997) to conclude that it is a major reason for financial problems in the industry. Unlike typical agency problems that arise through a separation of ownership and control McMaster proposed that the problem of agency in football arises because there is no division between ownership and control. Many football clubs are owned by a small number of directors who have almost total control over the issuing of shares and thus restrict the supply of shares and prevent a free market for shares existing. Thus where the football club may be performing poorly in financial terms there is little chance of the owners being removed. Again the argument that wider share ownership will resolve the financial performance of football clubs is undermined by Szymanski and Hall's results.

In most industries businesses exit when they have financial difficulties. Evidence in football suggests this is much less common. Rarely do football clubs go out of business. This might suggest football is a very different type of business. Two areas are worthy of consideration in this respect. The first has already been raised and that is the objective of owners of football clubs. Sloane's (1971) view that football clubs are utility maximisers is instructive. Owners of football clubs may have other reasons for their involvement in the football industry than a purely financial one. Sloane suggested that owners of football clubs invest their money for psychological reasons such as the urge for power, the desire for prestige, the propensity for group identification and the related feeling of group identity. This would suggest owners of football clubs have greater non-economic objectives. This might be the win maximisation objective referred to previously. Maximising playing success enhances the owner's relationships with the team's supporters. This relationship between owner and supporter leads into the second reason why football clubs rarely go out of business.

\section{Proposition 2: The lack of a market for corporate control in football is a contributory factor to poor financial performance and poor corporate governance in football.}

The second issue relates to the nature of the customer in football. Hawkes (1998) suggests that a football supporter is more than a mere customer and that the fan's relationship to a club extends beyond that of a conventional customer. If a firm in an industry exits, customers will usually switch their purchases to a different organisation. In football, supporters usually have a loyalty to their team that goes well beyond that in most conventional industries. Hawkes further contends that supporters as a special type of customer are a unique stakeholder group, which deserve special consideration when the football club is setting goals. In addition, in most other industries when a firm exits the remaining firms stand to benefit from additional revenues from customers that transfer. This effect is likely to be less in football. The loss of a close rival may lead to less revenue being generated for other firms and the industry as a whole.

\section{Proposition 3: The exit of a close rival(s) in football will lead to lower revenues for the other team(s).}

This view that football supporters as a special type of customer should have a say in the running of their football club is one that would easily fit stakeholder approaches to 
corporate governance. However, stakeholder models are similar to agency and stewardship models in providing models of governance at the level of the firm only. Whilst there are issues of governance at the level of the firm in football there are also issues of governance at the level of the league. For example, the rules of the Premiership are determined by the member teams and can be changed when three-quarters of the teams agree to such changes. The previously referred to breakaway of the Premier League clubs from the football league came about because of these changes. The question of who governs the league and who governs the clubs and the relationship between the governance of the league and the governance of the clubs are not easily answered using agency, stewardship or stakeholder approaches. Similar to the previously raised point about the relationships between the different regulatory bodies in football, FIFA, UEFA and the FA the relationship between the firm in football and the league could be viewed as a network and further examination of these network relationships could provide a useful framework to explore governance in football and professional sport in general.

\section{Proposition 4: The relationship between football clubs and the league is similar to a network relationship.}

\section{Proposition 5: The relationship between football's regulatory bodies, FIFA, UEFA, the FA with the league and football clubs is similar to a network relationship.}

Further support for the contention that there is potential for exploring governance issues in football from a network perspective can be found by returning to the issue of promotion and relegation. English league football, unlike all US team sports has an open league system with promotion and relegation to enable the best teams in the lower division to move into higher divisions and replace the weakest teams in the higher divisions. There are a number of issues relating to governance here. First, the number of teams to be promoted and relegated is an issue for the league, but the teams in the league determine the rules of the league on such matters. This means there may large elements of self-interest that influences the outcome. Recently, Sepp Blatter, the president of FIFA has suggested the English Premiership should be reduced from its current size of 20 teams to 16 or 18 . For this to happen the three-quarters of the existing Premiership teams would have to agree to the change. Thus, there is a role for teams (firms) in the governance of the league. In addition there are questions about the role of the national governing body, the FA in this issue. This suggests the possibility of a network of relationships in the governance of firms and the sports leagues in football.

\section{Proposition 6: The relationship between football clubs and the league lead to league rules being determined by football clubs' self-interest.}

A second issue relating to governance arising from promotion and relegation is a financial issue for the teams concerned. Since the setting up of the Premiership in 1992 there has been a widening of the revenue gap between the Premiership and the Football League. This has primarily been the result of the change in redistribution rules that occurred with the set up of the new league. This has meant the teams in the Premiership now retain a higher share of income streams from broadcasting. Whilst there has been an 
extremely large growth of television revenues in football over the last ten years, the vast proportion of these revenues have gone to the teams in the Premiership. This growth in inequality between the leagues may encourage Football League clubs to overspend on players and salaries in an attempt to gain promotion. It may have similar effects on the spending of Premiership clubs threatened with relegation. The potential larger rewards by gaining a place in the highest league may lead clubs into financial difficulties and clear issues of firm governance. The fact that around 20 football clubs in England have entered financial administration in the last three years could be largely attributed to the increasing inequalities between the leagues. This suggests the governance of football clubs is not working. As clubs are members of the league this has implications for the league. When leagues become unbalanced, there is pressure from those at the top to form breakaway leagues, as was the case with the setting up of the Premier League, in order to attain a greater share of revenue.

\section{Proposition 7: Increased financial inequality between football clubs decreases the structural stability of football leagues.}

A further dimension to the issues of governance in terms of relationships between clubs and the league emerges from teams competing in a number of different competitions simultaneously. The leading teams in the Premiership and the FA and League Cup winners qualify for European competitions that allow them access to additional revenues not available to non-qualifying clubs. The effect of this is to further widen the inequality in income within the Premier League itself. The lack of redistribution creates incentives for teams to break away from present league structures and consider cross-national leagues. The G14 group of 14 (now 18 teams) of the largest clubs in Europe was set up to further their interests and try and obtain a greater share of revenue. For what reasons and in whose interest are these clubs making such decisions? The significance of these issues is profound for the football industry in England. Further inequality is likely to lead to further fragmentation of the league structure in England and opens up questions on the governance of the industry and the long-term financial viability of an open league structure.

\section{Conclusion}

To sum up, there are a number of factors in the football industry that raise questions about the applicability of existing models of corporate governance. These include the complexities of governance relationships between the different levels of governing bodies, national, European and world as well as the domestic relations between clubs, the league and the national football associations. In addition, football is similar to other team sports in having a number of peculiarities not applicable to other industries. Clubs must actively cooperate to produce their (joint) product. The likelihood that evenly matched contests will attract more customers suggests that leagues should be of near-equal ability, as dominance by a small number of clubs reduces both the interest of the viewing public and the overall amount of attendance revenue the league should receive. In addition, sporting leagues have a number of organisational issues that are not applicable to other industries including decisions on format, hierarchy, multiplicity, membership and 
governance. Recent reports that UEFA the governing body for European club and country competitions is considering bringing in specific rules relating to the governance of clubs who are attached to national governing bodies illustrates the network systems that appear in the governance of football. Football is not unique in this respect, other teams sports have similar governance relationships. It is for these reasons that this research will be developed to examine the network relations in the governance of football and attempt to provide a network model of governance.

\section{References}

Agle, B.R., Mitchell, R.K. and Sonnenfeld, J.A. (1999) 'Who matters to CEOs? An investigation of stakeholder attributes and salience, corporate performance and CEO values', Academy of Management Journal, Vol. 42, No. 5, pp.507-525.

Aguilera, R.V. and Jackson, G. (2003) 'The cross-national diversity of corporate governance: dimensions and determinants', Academy of Management Review, Vol. 28, No. 3, pp.447-465.

Aoki, M. (2000) Information, Corporate Governance, and Institutional Diversity: Competitiveness in Japan, the USA, and the Transnational Economies, Oxford: Oxford University Press.

Baimbridge, M., Cameron, S. and Dawson, P. (1996) 'Satellite television and the demand for football: a whole new ball game?', Scottish Journal of Political Economy, Vol. 43, No. 3, pp.317-333.

Berle, A. and Means, G. (1932) The Modern Corporation and Private Property, New York: Macmillan.

Berman, S.L., Wicks, A.C., Kotha, S. and Jones, T.M. (1999) 'Does stakeholder orientation matter? The relationship between stakeholder management models and firm financial performance', Academy of Management Journal, Vol. 42, No. 5, pp.488-506.

Cairns, J. (1987) 'Evaluating changes in the Scottish football league', Applied Economics, Vol. 19, No. 2, pp.259-275.

Clarkson, M.B.E. (1995) 'A stakeholder framework for analysing and evaluating social corporate performance', Academy of Management Review, Vol. 20, No. 1, pp.92-117.

Cyert, R.M. and March, J.G. (1963) A Behavioural Theory of the Firm, Englewood Cliffs, New Jersey: Prentice Hall.

Daily, C.M., Dalton, D.R. and Cannella, Jr., A.A. (2003) 'Corporate governance: decades of dialogue and data', Academy of Management Review, Vol. 28, No. 3, pp.371-382.

Dalton, D.R., Daily, C.M., Certo, S.T. and Roengpitya, R. (2003) 'Meta analyses of financial performance and equity: fusion or confusion?', Academy of Management Journal, Vol. 46, No. 1, pp.13-26.

Davis, J.H., Schoorman, F.D. and Donaldson, L. (1997) 'Toward a stewardship theory of management', Academy of Management Review, Vol. 22, No. 1, pp.20-47.

Demsetz, H. and Lehn, K. (1985) 'The structure of corporate ownership: causes and consequences', Journal of Political Economy, Vol. 93, No. 1155-1177.

Denis, D.K. and McConnell, J. (2003) 'International corporate governance', Journal of Financial and Quantitative Analysis, Vol. 38, No. 1, pp.1-36.

Donaldson, L. (1990) 'The ethereal hand: organisational economics and management theory', Academy of Management Review, Vol. 15, No. 3 pp.369-381.

Donaldson, L. and Davis, J.H. (1991a) 'Stewardship theory or agency theory: CEO governance and shareholder returns', Australian Journal of Management, Vol. 16, No. 1, pp.49-64.

Donaldson, L. and Davis, J.H. (1991b) 'Boards and company performance - research challenges the conventional wisdom', Corporate Governance: An International Review, Vol. 2, No. 3, pp.151-160. 
Donaldson, L. and Davis, J.H. (1994) 'Boards and company performance - research challenges the conventional wisdom', Corporate Governance: An International Review, Vol. 2, pp.151-160

Downward, P. and Dawson, A. (2000) The Economics of Professional Team Sports, Boston: Routledge.

Downward, P. and Dawson, A. (2003a) 'Clearing up anomalies in championship models of team sports', Staffordshire University Division of Economics Working Paper, Vol. 4.

Downward, P. and Dawson, A. (2003b) 'Measuring short-run uncertainty of outcome in sporting outcomes: a comment', Staffordshire University Division of Economics Working Paper, Vol. 5.

Donaldson, L. and Preston, L.E. (1995) 'The stakeholder theory of the corporation: concepts, evidence and implications', Academy of Management Review, Vol. 20, No. 1, pp.65-91.

Eisenhardt, K.M. (1989) 'Agency theory: an assessment and review', Academy of Management Review, Vol. 14, No. 1, pp.57-74.

El-Hodiri, M. and Quirk, J. (1971) 'An economic model of a professional sports league', Journal of Political Economy, Vol. 70, pp.1302-1319.

Fama, E.F. (1980) 'Agency problems and the theory of the firm', Journal of Political Economy, Vol. 88, pp.288-307.

Fama, E.F. and Jensen, M.C. (1983) 'Separation of ownership and control', Journal of Law and Economics, Vol. 26, pp.301-325.

Flynn, M.A. and Gilbert, R.J. (2001) 'The analysis of professional sports leagues as joint ventures', The Economic Journal, Vol. 111, pp.F27-F46.

Fort, R. (2000) European and North American sport differences', Scottish Journal of Political Economy, Vol. 47, No. 4, pp.431-455.

Fort, R. and Quirk, J. (1992) Pay Dirt, Princeton, New Jersey: Princeton University Press.

Fort, R. and Quirk, J. (1995) 'Cross-subsidization, incentives and outcomes in professional team sports leagues', Journal of Economic Literature, September, Vol. 33, pp.1265-1299.

Freeman, R.E. (1984) Strategic Management: A Stakeholder Approach, Boston: Pitman.

Freeman, R.E. and Evan, W.M. (1990) 'Corporate governance: a stakeholder interpretation', The Journal of Behavioural Economics, Vol. 19, No. 4, pp.337-359.

Hall, S., Szymanski, S. and Zimbalist, A. (2002) Testing Causality Between Team Performance.

Hawkes, T. (1998) 'Scoring an own goal? Ethical issues in the UK professional soccer business', Business Ethics: A European Review, Vol. 7, No. 1, pp.37-42.

Hendry, J. (2001) 'Economic contracts versus social relationships as a foundation for normative stakeholder theory', Business Ethics: A European Review, Vol. 10, No. 3, pp.223-232.

Himmelberg, C.P., Hubbard, R.G. and Palia, D. (1999) 'Understanding the determinants of managerial ownership and the link between ownership and performance', Journal of Financial Economics, Vol. 53, pp.353-384.

Jawahar, I.M. and McLaughlin, G.L. (2001) 'Toward a descriptive stakeholder theory: an organizational life cycle approach', Academy of Management Review, Vol. 26, No. 3, pp.397-414.

Jennett, N. (1984) 'Attendances, uncertainty of outcome and policy in the Scottish football league', Scottish Journal of Political Economy, Vol. 31, No. 2, pp.176-198.

Jensen, M.C. (1993) 'The modern industrial revolution, exit, and the failure of internal control systems', Journal of Finance, Vol. 48, pp.831-880.

Jensen, M.C. (2002) 'Value maximisation, stakeholder theory and the corporate objective function', Business Ethics Quarterly, Vol. 12, No. 2, pp.235-256.

Jensen, M.C. and Meckling, W.H. (1976) 'Theory of the firm: managerial behaviour, agency costs and ownership structure', Journal of Financial Economics, Vol. 3, pp.305-360. 
Jensen, M.C. and Murphy, K. (1990) 'Performance pay and top management incentives', Journal of Political Economy, Vol. 98, pp.225-263.

Jones, T.M. (1995) 'Instrumental stakeholder theory: a synthesis of ethics and economics', Academy of Management Review, Vol. 20, No. 2, pp.404-437.

Jones, T.M. and Wicks, A.C. (1999) 'Convergent stakeholder theory', Academy of Management Review, Vol. 24, No. 2, pp.206-221.

Kesenne, S. (1996) 'League management in professional team sports with win maximising clubs', European Journal of Sports Management, Vol. 2, No. 2, pp.14-22.

Kesenne, S. (2000a) 'Revenue sharing and competitive balance in professional team sports', Journal of Sports Economics, Vol. 1, No. 1, pp.56-65.

Kesenne, S. (2000b) 'The impact of salary caps in professional team sports', Scottish Journal of Political Economy, Vol. 47, No. 4, pp.422-430.

McMaster, R. (1997) 'The market for corporate control in professional football: is there an agency problem', Economic Affairs, Vol. 17, No. 3, pp.25-29.

Mitchell, R.K., Agle, B.R. and Wood, D.J. (1997) 'Toward a theory of stakeholder identification and salience: defining the principle of who and what really counts', Academy of Management Review, Vol. 22, No. 4, pp.853-886.

Neale, W.C. (1964) 'The peculiar economics of professional sports: a contribution to the theory of the firm in sporting competition and in market competition', Quarterly Journal of Economics, February, Vol. 78, No. 1, pp.1-14.

Noll, R.G. (2003) 'The organization of sports leagues', Oxford Review of Economic Policy, Vol. 19, No. 4, pp.530-551.

Peel, D. and Thomas, D. (1988) 'Outcome uncertainty and the demand for football: an analysis of match attendances in the English football league', Scottish Journal of Political Economy, Vol. 35, No. 3, pp.242-249.

Peel, D. and Thomas, D. (1992) 'The demand for football: some evidence on outcome uncertainty', Empirical Economics, Vol. 17, pp.323-331.

Peel, D. and Thomas, D. (1997) 'Handicaps, outcome uncertainty and attendance demand', Applied Economics Letters, Vol. 4, pp.567-570.

Phillips, R., Freeman, R.E. and Wicks, A.C. (2003) 'What stakeholder theory is not', Business Ethics Quarterly, Vol. 13, No. 4, pp.479-502.

Rottenberg, S. (1956) 'The baseball players' labour market', Journal of Political Economy, Vol. 64, pp.242-258.

Rowley, T.J. (1997) 'Moving beyond dyadic ties: a network theory of stakeholder influences', Academy of Management Review, Vol. 22, No. 4, pp.887-910.

Schmidt, M. and Berri, D. (2001) 'Competitive balance and attendance: the case of major league baseball', Journal of Sports Economics, Vol. 2, No. 2, pp.145-167.

Shleifer, A. and Vishny, R.W. (1997) 'A survey of corporate governance', Journal of Finance, Vol. 52, No. 2, pp.737-783.

Simon, H.A. (1959) 'Theories of decision-making in economics and behavioural science', American Economic Review, Vol. 49, No. 3, pp.253-283.

Sloane, P.J. (1971) 'The economics of professional football: the football club as a utility maximiser', Scottish Journal of Political Economy, Vol. 17, No. 2, pp.121-146.

Szymanski, S. (2001) 'Income inequality, competitive balance and the attractiveness of team sports: some evidence and a natural experiment from English soccer', Economic Journal, Vol. 111, pp.F69-F84.

Szymanski, S. (2003) 'The economic design of sporting contests', Journal of Economic Literature, Vol. 41, pp.1137-1187. 
Szymanski, S. and Hall, S. (2003) 'Making money out of football', The Business School, Imperial College, London Working Paper.

Szymanski, S. and Smith, R. (1997) 'The English football industry: profit, performance and industrial structure', International Review of Applied Economics, Vol. 11, No. 1, pp.135-153.

Trevino, L.K. and Weaver, G.R. (1999) 'The stakeholder research tradition: converging theorists - not convergent theory', Academy of Management Review, Vol. 24, No. 2, pp.222-227.

Vrooman, J. (1995) 'A general theory of professional sports leagues', Southern Economic Journal, Vol. 61, No. 4, pp.971-990.

Vrooman, J. (1997) 'Franchise free agency in professional sports leagues', Southern Economic Journal, Vol. 64, No. 1, pp.191-219.

Vrooman, J. (2000) 'The economics of American sports leagues', Scottish Journal of Political Economy, Vol. 47, No. 4, pp.364-397.

Walsh, J.P. and Seward, J.K. (1990) 'On the efficiency of internal and external corporate control mechanisms', Academy of Management Review, Vol. 15, pp.421-458.

Whitney, J. (1988) 'Winning games versus winning championships: economics of fan interest and team performance', Economic Inquiry, Vol. 26, pp.703-724.

Williamson, O. (1984) 'Corporate governance', Yale Law Journal, Vol. 93, pp.1196-1230.

Zimbalist, A. (2003) 'Sport as business', Oxford Review of Economic Policy, Vol. 19, No. 4, pp.503-511.

\section{Bibliography}

Cairns, J., Jennett, N. and Sloane, P.J. (1986) 'The economics of professional team sports: a survey of theory and evidence', Journal of Economic Studies, Vol. 13, No. 1, pp.3-80.

Coles, J.W., McWilliams, V.B. and Sen, N. (2001) 'An examination of the relationship of governance mechanisms to performance', Journal of Management, Vol. 27, pp.23-50.

Daily, C.M., Dalton, D.R., Certo, S.T. and Roengpitya, R. (2003) 'Meta-analyses of financial performance and equity: fusion or confusion?', Academy of Management Journal, Vol. 46, No. 1, pp.13-26.

Dobson, S. and Goddard, J. (2001) The Economics of Football, Cambridge: University Press Cambridge.

Eng, L.L. and Mak, Y.T. (2003) 'Corporate governance and voluntary disclosure', Journal of Accounting and Public Policy, Vol. 22, pp.325-345.

Fort, R. (2000) 'European and North American sports differences', Scottish Journal of Political Economy, Vol. 47, No. 4, pp.431-455.

Fort, R.D. (2003) Sports Economics, New Jersey: Pearson Education.

Gillette, A.B., Noe, T.H. and Rebello, M.J. (2003) 'Corporate board composition, protocols and voting behaviour: experimental evidence', The Journal of Finance, Vol. 58, No. 5, pp.1997-2031.

Hamil, S., Michie, J. and Sharot, T. (1999) The Business of Football: A Game of Two Halves, London: Mainstream Publishing.

Hoehn, T. and Szymanski, S. (1999) 'The Americanisation of European football', Economic Policy, Vol. 28, pp.205-242.

Hutchinson, M. and Gul, F.A. (2003) 'Investment opportunity set, corporate governance practices and firm performance', Journal of Corporate Finance, Vol. 182, pp.1-20.

Leeds, M. and von Allmen, P. (2002) The Economics of Sports, Boston: Pearson Education. 
Mason, D. (1997) 'Revenue sharing and agency problems in professional team sport: the case of the national football league', Journal of Sports Management, Vol. 11, pp.203-222.

Noll, R.G. (2002) 'The economics of promotion and relegation in sports leagues: the case of English football', Journal of Sports Economics, Vol. 3, No. 2, pp.169-203.

Shen, W. (2003) 'The dynamics of the CEO-board relationship: an evolutionary perspective', Academy of Management Review, Vol. 28, No. 3, pp.466-476.

Szymanski, S. and Kuypers, T. (1999) Winners and Losers: The Business Strategy of Football, London: Penguin.

\section{Note}

1 Deloitte and Touche Annual Review of Football Finance, www.deloitte.co.uk/sectors/ footballreview 